\title{
Communicative performance in the written discourse of undergraduate students: what can literature offer?
}

\author{
Kingsley Oluchi Ugwuanyi \\ Northumbria University at Newcastle, UK \\ Article received 18/02/17, accepted 05/06/17, final version 31/08/17 \\ DOI: https://doi.org/10.5565/rev/jt13.705
}

\begin{abstract}
This study examined two groups of students of the University of Nigeria who were taught using two approaches (literature-based and grammar-based) in order to measure the effect of the approaches on their communicative performance. The data comprised 100 essay scripts (50 for each group) qualitatively analysed based on content, expression, organisation and mechanical accuracy; and also quantitatively analysed using SPSS in order to measure the difference between the two groups. The findings show that there are significant differences in the performance of the two groups in favour of the literature-based approach. The study closes with conclusions and recommendations for SLT pedagogy. The findings of this study supports Krashen's (1982) Naturalist Approach to language learning, which has farreaching implications for the field.
\end{abstract}

Keywords: communicative performance/competence, language teaching/learning, literature, applied linguistics

\section{Résumé}

Cette étude examine deux groupes d'étudiants de l'Université du Nigeria qui ont été enseignés en utilisant deux approches (basée sur la littérature et la grammaire) afin de mesurer l'effet des approches sur leur performance communicative. Les données comprennent 100 scripts d'essai (50 pour chaque groupe) analysés qualitativement en fonction du contenu, de l'expression, de l'organisation et de la précision mécanique; Et également analysées quantitativement en utilisant SPSS afin de mesurer la différence entre les deux groupes. Les résultats montrent qu'il existe des différences significatives dans la performance des deux groupes en faveur de l'approche basée sur la littérature. L'étude se termine par des conclusions et des recommandations pour la pédagogie SLT. Les résultats de cette étude soutiennent l'approche naturaliste de Krashen (1982) à l'apprentissage des langues, qui a des implications de grande envergure dans le domaine.

Mots clés: Compétences / compétences communicatives, enseignement / apprentissage des langues, littérature, linguistique appliquée

\section{Resumen}

Este estudio examina dos grupos de estudiantes de la Universidad de Nigeria que fueron enseñados usando dos enfoques (basados en la literatura y en la gramática) para medir el efecto de los enfoques en su desempeño comunicativo. Los datos comprenden 100 guiones de ensayo (50 para cada grupo) cualitativamente analizados basados en el contenido, la expresión, la organización y la exactitud mecánica; Y también se analizó cuantitativamente con SPSS para medir la diferencia entre los dos grupos. Los hallazgos 
muestran que hay diferencias significativas en el desempeño de los dos grupos a favor del enfoque basado en la literatura. El estudio concluye con conclusiones y recomendaciones para la pedagogía SLT. Los hallazgos de este estudio apoyan el Enfoque Naturalista de Krashen (1982) al aprendizaje de idiomas, que tiene implicaciones de largo alcance para el campo.

Palabras clave: Rendimiento / competencia comunicativa, enseñanza / aprendizaje de idiomas, literatura, lingüística aplicada

\section{Introduction}

It is now agreed that the goal of every language teaching - first, second, or foreign - is to develop the communicative competence of the learners. Since Chomsky, the question of competence has taken the centre-stage of applied linguistics research, giving birth to, and generating debates about, different theories of (communicative) competence. Developing learners' competence is particularly important in second language environment for several reasons. Foremost, the learners may not have enough 'comprehensible input' as would have those in a first language environment. This places more demands on the teachers to explore more ways, or methods, that can engage the learners more actively, and present to them means of encountering the language enough to grow their communicative abilities. The search for these 'ways' or 'means' has been the goals of several methods, theories and models/approaches of second language teaching and learning, each with obvious benefits and shortcomings. In all of these, the real actual language performance of the learners is hardly tested. Though many have pointed out a clear difference between communicative competence and communicative performance, there is still a gap as to the testing of the performance of the learners. The attempt to analyse or measure the level of knowledge which the speakers of a language have and exhibit is as old as linguistics as a discipline. Such earlier attempts include the works of Ferdinand de Saussure (1916) where he used the terms 'langue' and 'parole' in his description. Later, Chomsky (1957, 1965) investigated this further, highlighting the notions of 'competence' and 'performance'. Since Chomsky, linguists have come to agree that competence refers to "speakers' knowledge of their language, the system of rules which they have mastered so that they are able to produce and understand an indefinite number of sentences, and to recognize grammatical mistakes and ambiguities" (Crystal, 2008, p. 92). Even though the term 'competence' is traceable to Chomskyan linguistics, the concept 'communicative competence' has a different origin and perhaps a slightly different understanding. The term as explored by Chomsky was largely linguistic (Paulston, 1992) because it fails to recognize the sociolinguistic aspects of language use. It is, 
therefore, on this note that the Chomskyan notion of competence has been adjudged inadequate (Hymes, 1967 \& 1972; Yano, 2003). Consequently, the term 'communicative competence' was coined by the anthropological linguist, Dell Hymes (ibid). Communicative competence, therefore, has to do with how a language user is able to pass judgements of grammaticality as well as recognize acceptable speech acts in a social situation (Bell, 1976; Osorio \& Insuasty, 2015).

Since the introduction of the concept by Hymes, researchers have continued to investigate aspects of the concept and to measure the level of knowledge of speakers. In second language teaching (SLT), the argument has been whether the processes involved in acquiring a first language can as well be followed in learning a second language (Krashen, 1982). Though the concepts 'acquisition' and 'learning' have continued to generate arguments, this study follows Krashen (1982) and Ugwuanyi and Chukwu (2016) to say that the terms can be used interchangeably so far as they both refer to the processes of 'picking up' a language. Several researchers (e.g., Akwanya, 2007; Canale \& Swain, 1980; Hall, 2005; Krashen, 1982; and Kramsch \& Kramsch, 2000) have argued very forcefully that since learning a language largely involves the learners being given enough exposure to the language, the processes involved in learning a first language can also be employed in teaching a second language. One way of doing this is to give the learners activities that can immerse them into the language being learned. Activities such as watching movies, listening to native/advanced speakers, reading literary texts have been suggested. It is the goal of this study to explore the role of literature as 'comprehensible input' (Krashen, 1982) in measuring the communicative performance of the population of the study.

\section{Competence-performance dichotomy}

The idea of the inherent knowledge the speakers of language have of their language started off simply as linguistic competence. As hinted earlier, many applied linguists have investigated this, thereby expanding the scope of the concept. Today, we not only talk about linguistic or grammatical competence, but also about sociolinguistic (or even sociocultural) competence, discourse competence, strategic competence, pragmatic competence, interactional competence, formulaic competence, and actional competence (Celce-Mercia, 2007). The work of Canale and Swain (1980) is seminal not only because it was the first to clearly discuss communicative competence in the light of second language acquisition (SLA), but because it helped to bring the competence-performance dichotomy to the fore in the 
discussion of communicative competence in SLA. Most Chomskyan linguists (e.g., Kempson, 1979) adopt the position that competence should be used to refer exclusively to rules of grammar, and that communicative competence should be identified with the theory performance. Kempson (ibid) writes that 'a theory which characterizes the regularities of language is a competence theory', while a theory which 'characterizes the interaction between that linguistic characterization and all other factors which determine the full gamut of regularities of communication is a theory of performance ( $\mathrm{pp}$ 54-55). In other words, any theory that characterises the knowledge of language (that is, the communicative competence) is a performance theory.

Another argument Kempson (ibid) pursues quite doggedly is that the study of competence should logically precede the study of performance. According to her, this should be so because it is the knowledge one has (competence) that translates and gives life to what ones does with the language (performance). This position has been criticised (e.g. Canale and Swain, 1980). And since the position of this study is that the natural approach to language learning should be followed, it does not hold water which comes before the other. It is the position of this paper that such this-item-must-come-before-the-other approach will mechanise the learning process and may defeat the real essence of learning, which is mastering the entire gamut of the language.

Similarly, Canale and Swain (ibid) add that "communicative competence is to be distinguished from communicative performance, which is the realization of these competencies and their interaction in the actual production and comprehension of utterances under general psychological constraints that are unique to performance" (p. 6). They immediately add that such distinction is important in a second language environment so that teaching methods and instruments would be designed to address not only communicative competence, but also communicative 'performance'. The distinction made between communicative competence and communicative performance above appears to serve a more significant purpose in Second Language Learning (SLL) for the reason stated above. But in general terms, the concept of communicative competence (in this and many other models) is not thought of as including such factors that characterize performance. Canale and Swain (ibid) sum this up by saying that communicative competence should be understood to mean the interaction or relationships between the knowledge of the rules of a language (grammar) and the knowledge of the rules of language use. Bringing the notion of CC into SLL, they argue that since there is no agreement among scholars as to what is the minimum level of 
skills necessary to communicate in a given language (even with what Van EK (1977) and Cummins (1976) call 'threshold level'), 'it is quite reasonable to assume that since in acquiring a first language the child seems to focus more on being understood than on speaking grammatically, then second language acquisition might be allowed to proceed in this manner' (Canale \& Swain, 1980, p. 10). What this implies is that the goal of SLT should be on internalizing the full package of the linguistic knowledge that would enable one to get one's meaning across without impediments. Mostly, this could be understood as the model of CC proposed by Canale and Swain.

This study, however, adopts a model of distinction between the two concepts simpler than what Canale and Swain present. This model draws a simple distinction between competence as 'knowing' and performance as 'doing'. Though this 'doing' implies putting the knowledge into use, we know also that some form of more concrete 'knowing' takes place in 'doing'. So our model is such that believes that the two, though may be understood separately, can be pursued together. In fact, when the goal of any model is to develop competence alone, the whole essence of language learning may be defeated because the learners may never gain a proficient mastery of the language in use. This is the model that Bataineh et al (2013) used in their study of Jordan university students' communicative performance.

\section{Literature as comprehensible input in SLT}

It is tenable to say that most languages, especially those that have been codified into writing, have their literatures. Literary works are part and parcel of what constitute a language. It is the space where language takes place in varying forms. Aristotle (trans., 1920) has argued that the art form which imitates by means of language alone is literature. If this is so, any discussion or description of any language that neglects the literature of that language leaves a lot to be desired. According to Akwanya (2007), divorcing literature from language is counterproductive. Many scholars have argued that because of its communicative values, literature should play a central role in language teaching and learning (Akwanya, 2005; AlDarwish \& Shuqair, 2015; Rai, 2012; and Shazu, 2014). They hold that any language teaching curriculum which separates literature from language teaching has denied itself (and the learners) an essential ingredient in the language learning process. Williams (as cited in Otagburuagu, 2007) sums up the point being made here in the following lines: 
Literature in a first or a second language confronts the student with various operations of language and the need to elucidate its meaning. Since literature organises language in the most exemplary fashion, the second language learner must be aware of the importance of applying the language of literature as a model for his own use. The teaching of literature has the practical value of enabling the student to learn about the second language as well as use it. (pp. 195-196)

In Adichie's Americanah (2013), for instance, we read of such expressions as: 'Sometimes not believing herself' (p. 15). This is the kind of expression that may never pass as examples of sentence in a grammar class, but which, nevertheless, has been so used in the text. And as part of a discourse, their full meaning and, indeed grammaticalness, are to be recuperated from the discourse to which they are only a part. This is practical encounter with language; it is grammar at its best, since thought and speech take place as discourse, and not as sentence (Ugwuanyi and Chukwu, 2016).

So many scholars (e.g., Akwanya, 2005) have written that literature demonstrates classic models of language which learners of a language can draw from. Thus Akwanya (2005, p. 28) posits that 'literature is unique among the works of language to the extent that it may be studied simply as language.' It is in literature that one can see all the possible structures and linguistic patterns that a given language permits. One of the reasons for this is that to be efficient in a language, one needs to acquire much more than the knowledge of the structures of the language. Language use entails some knowledge of the social milieu, cultural values and habits of thought of the language community of the target language. Concerning this, Carpio and Carpio (2015) said that knowing and speaking a second language can imply change of behaviour, for instance, the modification of certain attitudes to perception of others as well as our exterior environment; and that learning another language may imply expanding our horizons and enriching ourselves. It also implies respect for cultural and linguistic diversity.

It follows, therefore, that every correct language use entails a correct attitude to and in the language. It is not probable that the learners of a second or foreign language can acquire all of these simply by the study of grammar in classrooms. If an effort must be made to imbibe such elements of the value system embedded in the target language, and which fixes its grammar and meaning, recourse should be made to authentic texts such as literature, which have the potential of exposing the reader to those elements inscribed in them. In studying literature in order to tap these communicative values inherent in them, emphasis should not only be placed on literariness, but on communicative or linguistic features. In fact, some have suggested that where the reading of literature is for the purpose of language 
learning, literariness should be sacrificed at the altar of discovering the linguistic features being sought for. While one may not completely agree with that, it has to be emphasised here that reading literary texts with the mind of developing some level of communicative competence has proved helpful.

There are several other ways of encountering the language such as listening to more advanced users, but some exposure to the language through the reading of literary texts stands out. Akwanya (2010), who has pursued this argument vigorously, remarked that 'awareness of... linguistic practices [like making good compositions] can only come from sustained contact with language, especially through reading' (p. viii). He argues further that close attention to the content, the clause structure, sentence patterns, word order, the variety of vocabulary, the punctuation practices, and to some other linguistic features of the material one in reading is bound to pay off when one is faced with one's own essay writing tasks. Such other structures like idiomatic collocations, phrasal verbs, vocabulary development, grammatical structures and parts of speech, reading skills, discourse strategies etc can be acquired through the reading of literature, and indeed, there is no doubt that much more communicative features abound in literature, if it is critically linguistically read. This is a position I have fully pursued else (Ugwuanyi, 2013).

\section{Method}

The design of this study was a triangulation of qualitative and quantitative methods. The study examined and compared the written discourse of two groups of students. This kind of comparison is believed to help to highlight the effect of literature in the development of communicative competence and performance. This was based on the magnitude of the exposure of the members of each group to literature. As the scope of this work reveals and as the instrument permits, the study was concerned with the written discourse only.

Part of the motivation for this research was the relative poor performance of the students the researcher has taught in composition courses like Advanced Prose Composition offered at the Department of English and Literary Studies, University of Nigeria - and of course in almost every other department of English in Nigeria. So my students at the University of Nigeria constituted the population for this study. The first group, students of Combined Arts, took mostly grammar lessons; while the second group, students of English and Literary Studies, took more than fifteen literature courses. But the two groups took equal 
number of grammar courses. So the purpose of the study was to examine the written compositions of the members of these groups to see whether greater exposure to literature could enhance communicative performance. The examination scripts of these students were examined to test for this. For each group, fifty (50) essays were analysed.

Because of the nature of the variables involved in this research, systemic sampling technique was preferred. The instruments were documents, examination scripts. Unlike the other instruments, this avoids the tendency of the research being controlled. Hall (2005) has pointed out that in any analysis of documents, there must be taken into consideration what he calls the 'history of production of the documents'. Knowing this entails knowing why, how and under what circumstances the documents were produced. All this were taken into account in the analysis section of this paper. There were four criteria for the measurement of performance in compositions based on the marking scheme of many examination bodies, especially West African Examination Council (WAEC). These are content (how relevant to the central theme are the ideas in the essay), expression (such qualities as clarity and general appropriateness of style, and judicious and competent use of figurative language), organisation (suitable opening, adequate development, good paragraphing, balance, coherence and a suitable conclusion), and mechanical accuracy (grammaticality, punctuation and spelling). A critical examination of these criteria reveals that some elements overlap. But this is not as important as the fact that they cover the essential ingredients of good writing. A composition is adjudged good if it scores high in all of the above. So the essays analysed were graded based on these criteria. Because the study involved descriptive statistics, SPSS was used to show, graphically, the performance of the two groups, and then make some interpretive and comparative conclusions.

\section{Presentation of Data and Analysis}

The two groups were called Group One and Group Two. In each, fifty essays were examined. Group One comprised the essays of students exposed to literature classes, with each student having read at least forty literary texts including novels, plays and poems. Effort was made to make sure that these students read these texts because they were expected to discuss them. Group Two took mainly grammar lessons. It has to be said also that Group One also received the same grammar lessons that were taught Group Two. So it may not be untenable to say the two groups had equal exposure to grammar lessons. 
So each of the essays was analysed and judged using the criteria of content, organisation, expression and mechanical accuracy. Essays in WAEC are graded to score 50 marks; that is, 10 marks for content, 10 for organisation, 10 for mechanical accuracy and 20 for expression. Obviously, expression should get the highest, for it tests the students' ability to mobilise the entire linguistic repertoire at their disposal to make acceptable structures. Even though a different mark point was used in the analysis here, more points were allotted to expression owing to the above reason. In this study, the essays were graded with the highest point of 25: expression receiving 10, while the rest receive 5 apiece.

For clarity of reading and interpretation, a simple framework was used in collating the results of the findings of this study. This framework used three tables: one presents the performance of Group One, the second presents that of Group Two, while the last presents a summary of the two.

\section{Group One}

Table 1: A Summary of the Performance of Group One

\begin{tabular}{|c|c|c|c|c|c|}
\hline $\mathbf{S} / \mathbf{N}$ & $\begin{array}{c}\text { CONTENT } \\
(5 \%)\end{array}$ & $\begin{array}{c}\text { ORGANISATION } \\
(5 \%)\end{array}$ & $\begin{array}{c}\text { MECHANICAL } \\
\text { ACCURACY } \\
(5 \%) \\
\end{array}$ & $\begin{array}{l}\text { EXPRESSION } \\
\text { (10\%) }\end{array}$ & $\begin{array}{l}\text { TOTAL } \\
(25 \%)\end{array}$ \\
\hline 1. & 3 & 3 & 2 & 5 & 13 \\
\hline 2. & 3 & 4 & 3 & 7 & 17 \\
\hline 3. & 3 & 3 & 3 & 6 & 15 \\
\hline 4. & 3 & 3 & 2 & 7 & 15 \\
\hline 5. & 2 & 3 & 2 & 7 & 14 \\
\hline 6. & 3 & 4 & 1 & 7 & 15 \\
\hline 7. & 3 & 3 & 2 & 5 & 13 \\
\hline 8. & 4 & 3 & 2 & 8 & 17 \\
\hline 9. & 3 & 3 & 3 & 4 & 13 \\
\hline 10. & 2 & 2 & 2 & 6 & 12 \\
\hline 11. & 3 & 2 & 3 & 6 & 14 \\
\hline 12. & 3 & 3 & 3 & 7 & 16 \\
\hline 13. & 4 & 4 & 3 & 7 & 18 \\
\hline 14. & 3 & 3 & 2 & 6 & 14 \\
\hline 15. & 3 & 2 & 2 & 6 & 13 \\
\hline 16. & 4 & 4 & 4 & 8 & 20 \\
\hline 17. & 5 & 4 & 4 & 8 & 21 \\
\hline 18. & 3 & 3 & 3 & 7 & 16 \\
\hline 19. & 2 & 2 & 2 & 6 & 12 \\
\hline 20. & 2 & 2 & 2 & 6 & 12 \\
\hline 21. & 2 & 2 & 2 & 6 & 12 \\
\hline 22. & 3 & 3 & 2 & 7 & 15 \\
\hline 23. & 3 & 2 & 2 & 6 & 13 \\
\hline 24. & 3 & 3 & 3 & 7 & 16 \\
\hline 25. & 4 & 4 & 3 & 7 & 18 \\
\hline
\end{tabular}




\begin{tabular}{|c|c|c|c|c|c|}
\hline 26. & 2 & 3 & 2 & 7 & 14 \\
\hline 27. & 4 & 4 & 3 & 6 & 17 \\
\hline 28. & 3 & 3 & 3 & 8 & 17 \\
\hline 29. & 3 & 3 & 2 & 7 & 15 \\
\hline 30. & 4 & 4 & 3 & 6 & 17 \\
\hline 31. & 2 & 2 & 2 & 7 & 13 \\
\hline 32. & 2 & 2 & 1 & 6 & 11 \\
\hline 33. & 2 & 2 & 0 & 6 & 10 \\
\hline 34. & 2 & 2 & 1 & 4 & 09 \\
\hline 35. & 3 & 3 & 3 & 5 & 14 \\
\hline 36. & 4 & 3 & 3 & 7 & 17 \\
\hline 37. & 3 & 2 & 2 & 6 & 13 \\
\hline 38. & 3 & 3 & 3 & 5 & 14 \\
\hline 39. & 3 & 3 & 3 & 6 & 15 \\
\hline 40. & 3 & 3 & 3 & 7 & 16 \\
\hline 41. & 3 & 2 & 1 & 5 & 11 \\
\hline 42. & 2 & 2 & 0 & 4 & 08 \\
\hline 43. & 2 & 2 & 2 & 6 & 12 \\
\hline 44. & 3 & 3 & 3 & 7 & 16 \\
\hline 45. & 3 & 3 & 3 & 6 & 15 \\
\hline 46. & 2 & 2 & 1 & 4 & 09 \\
\hline 47. & 3 & 3 & 2 & 7 & 15 \\
\hline 48. & 3 & 3 & 3 & 7 & 16 \\
\hline 49. & 3 & 2 & 2 & 5 & 12 \\
\hline 50. & 3 & 3 & 3 & 8 & 17 \\
\hline Total & 146 & 141 & 116 & 314 & 717 \\
\hline
\end{tabular}

\section{Group Two}

Table 2: A Summary of the Performance of Group Two

\begin{tabular}{lccccc}
\hline S/N & $\begin{array}{c}\text { CONTENT } \\
\mathbf{( 5 \% )}\end{array}$ & $\begin{array}{c}\text { ORGANISATION } \\
\mathbf{( 5 \% )}\end{array}$ & $\begin{array}{c}\text { MECHANICAL } \\
\text { ACCURACY (5\%) }\end{array}$ & $\begin{array}{c}\text { EXPRESSION } \\
\mathbf{( 1 0 \% )}\end{array}$ & $\begin{array}{c}\text { TOTAL } \\
\mathbf{( 2 5 \% )}\end{array}$ \\
\hline 1. & 3 & 3 & 2 & 7 & 15 \\
\hline 2. & 2 & 2 & 2 & 4 & 10 \\
\hline 3. & 2 & 2 & 2 & 6 & 11 \\
\hline 4. & 2 & 2 & 2 & 6 & 12 \\
\hline 5. & 2 & 2 & 2 & 4 & 10 \\
\hline 6. & 2 & 2 & 2 & 4 & 09 \\
\hline 7. & 2 & 2 & 1 & 4 & 08 \\
\hline 8. & 2 & 2 & 0 & 5 & 11 \\
\hline 9. & 2 & 2 & 2 & 4 & 09 \\
\hline 10. & 2 & 2 & 1 & 6 & 12 \\
\hline 11. & 2 & 2 & 2 & 4 & 09 \\
\hline 12. & 2 & 2 & 1 & 5 & 11 \\
\hline 13. & 2 & 2 & 2 & 4 & 10 \\
\hline 14. & 2 & 2 & 2 & 4 & 10 \\
\hline 15. & 2 & 2 & 2 & 4 & 08 \\
\hline 16. & 2 & 1 & 1 & 3 & 08 \\
\hline 17. & 2 & 2 & 1 & 4 & 10 \\
\hline 18. & 2 & 2 & 2 & 4 & 09 \\
\hline 19. & 2 & 2 & 1 & 5 & 11 \\
\hline 20. & 2 & 2 & 2 & 4 & 10 \\
\hline 21. & 2 & 2 & 2 & & \\
\hline
\end{tabular}




\begin{tabular}{|c|c|c|c|c|c|}
\hline 22. & 2 & 2 & 2 & 5 & 11 \\
\hline 23. & 2 & 2 & 2 & 4 & 10 \\
\hline 24. & 1 & 1 & 1 & 3 & 06 \\
\hline 25. & 2 & 2 & 2 & 4 & 10 \\
\hline 26. & 2 & 2 & 1 & 4 & 09 \\
\hline 27. & 2 & 2 & 1 & 4 & 09 \\
\hline 28. & 2 & 2 & 2 & 4 & 10 \\
\hline 29. & 2 & 2 & 2 & 5 & 11 \\
\hline 30. & 3 & 1 & 0 & 4 & 08 \\
\hline 31. & 2 & 2 & 2 & 4 & 10 \\
\hline 32. & 2 & 1 & 1 & 4 & 08 \\
\hline 33. & 2 & 2 & 2 & 6 & 12 \\
\hline 34. & 2 & 2 & 2 & 4 & 10 \\
\hline 35. & 2 & 2 & 1 & 4 & 09 \\
\hline 36. & 2 & 2 & 2 & 4 & 10 \\
\hline 37. & 2 & 2 & 2 & 4 & 10 \\
\hline 38. & 2 & 2 & 2 & 5 & 11 \\
\hline 39. & 2 & 2 & 2 & 5 & 11 \\
\hline 40. & 4 & 3 & 3 & 8 & 18 \\
\hline 41. & 2 & 2 & 2 & 5 & 11 \\
\hline 42. & 2 & 2 & 1 & 4 & 09 \\
\hline 43. & 2 & 1 & 1 & 4 & 08 \\
\hline 44. & 2 & 2 & 2 & 5 & 11 \\
\hline 45. & 2 & 2 & 2 & 5 & 11 \\
\hline 46. & 2 & 1 & 1 & 3 & 07 \\
\hline 47. & 2 & 2 & 1 & 3 & 08 \\
\hline 48. & 1 & 1 & 1 & 2 & 05 \\
\hline 49. & 3 & 3 & 2 & 7 & 15 \\
\hline 50. & 2 & 2 & 1 & 4 & 09 \\
\hline Total & 103 & 96 & 80 & 223 & 502 \\
\hline
\end{tabular}

\section{A summary of the two groups}

Table 3: A Summary of Tables 1 and 2

\begin{tabular}{lcc}
\hline & Group One & Group Two \\
\hline Content & 146 & 103 \\
\hline Organisation & 141 & 96 \\
\hline Mechanical Accuracy & 116 & 80 \\
\hline Expression & 314 & 223 \\
\hline Total & $\mathbf{7 1 7}$ & $\mathbf{5 0 2}$ \\
\hline
\end{tabular}

\section{Analysis}

As stated in the method section, this statistical description was done using a simple statistical method from SPSS (Statistical Package for Social Sciences).

$\mathrm{H}_{\mathrm{o}}$ : Reading literature has no effect on the written discourse competence of students.

$\mathrm{H}_{1}$ : Reading literature has effect on the written discourse competence of students.

$$
\mathrm{N}=100 \quad ; \quad \alpha=0.05
$$

\section{Group 1 Group 2}




\begin{tabular}{ll}
\hline $\mathrm{N}_{1}=50$ & $\mathrm{~N}_{2}=50$ \\
\hline$\delta_{1}=2111.22$ & $\delta_{2}=988.12$ \\
\hline$\mu_{1}=221$ & $\mu_{2}=154.2$ \\
\hline
\end{tabular}

Test Statistics;

\begin{tabular}{|c|c|c|c|}
\hline \multirow{3}{*}{\multicolumn{2}{|c|}{ Z }} & \multicolumn{2}{|c|}{$\underline{\mu}_{1}-\mu_{2}$} \\
\hline & & \multicolumn{2}{|c|}{$\sqrt{ } \underline{\delta}^{2} \underline{1}+\underline{\delta}^{2} \underline{2}$} \\
\hline & & \multicolumn{2}{|l|}{$\mathrm{N}_{1}$} \\
\hline & \multirow[t]{3}{*}{$=$} & 221 & $\begin{array}{l}-\quad 154.2 \\
\end{array}$ \\
\hline & & $\sqrt{ } \underline{2111.22}$ & $+\underline{988.12}$ \\
\hline & & 50 & 50 \\
\hline & \multirow[t]{2}{*}{$=$} & \multicolumn{2}{|c|}{66.8} \\
\hline & & $\sqrt{ } 42.22$ & 19.76 \\
\hline $\mathrm{Z}$ & 14.1 & $\alpha_{/ 2}(0$ & $25)=1.96$ \\
\hline
\end{tabular}

Decision Rule: Reject $H_{o}$ if $Z>\alpha_{/ 2}$. Accept if otherwise.

Conclusion: Since $\mathrm{Z}=14.1$, we do not accept $\mathrm{H}_{\mathrm{o}}$ and therefore conclude that reading literature has effect on the written discourse competence of students.

\section{INTERPRETATION:}

The analysis above shows that the reading of literature has an effect on the communicative performance of the learners of a language. The null hypothesis $\left(\mathrm{H}_{\mathrm{o}}\right)$ states that the reading of literary texts has no effect on the written discourse of students, while the alternative hypothesis $\left(\mathrm{H}_{1}\right)$ states that the reading of literature has an effect on the competence of the students. Group One is the number of students who read literature, while Group Two is the number of students who read less literature. The sample size is $\mathrm{N}=100$, showing the total number of observations taken. $\alpha$ shows the level of significance which is also the critical region. $\delta_{1}$ is the standard deviation of the means for group 1 and $\delta_{2}$ is the standard deviation of the means for group 2. $\mu_{1}$ is the average of population 1 (group 1) and $\mu_{2}$ is the average of population 2 (group 2). The test statistic shows the statistical formula that was applied which is the comparison of two independent samples. The data is assumed to follow the normal distribution. 
The decision rule says that Ho should be accepted if $Z>\alpha_{/ 2}$ since the data follows the standardized normal distribution with mean zero and variance 1 . The critical value for the test is obtained from the standard normal table at $\alpha=0.05$.

In conclusion, the reading above shows that since $Z=14.1$ is greater than $\alpha_{/ 2}(0.025)$ $=1.96$, we do not accept the null hypothesis $\left(\mathrm{H}_{\mathrm{o}}\right)$ and can say that the reading of literature can help to improve the communicative performance of the learners of a language. We can therefore accept the alternative hypothesis $\left(\mathrm{H}_{1}\right)$ but at $\alpha$ level of significance which is 0.05 .

Because of the number of students or scripts involved (which is necessary for a proper coverage or representation of the learners involved), a script-by-script presentation here appears cumbersome. But each of the hundred scripts representing the two groups was properly analysed using the criteria presented above with the results of that analysis presented in the tables. The average score for Group One is 14.35 (which is above average), while that of Group Two is 10.04. From all these, it is obvious that Group One, whose members were made to read very many literary texts as part of their language learning exercises, scored higher than Group Two, whose members read just a few texts. The general conclusion of this study, therefore, is that the reading of the literature of and in the target language can enhance not just the development of communicative competence, but significantly improve communicative performance.

But this conclusion raises other questions, and this work would not play ignorance to them. Now it is known that individual performance and abilities may come in here especially as not all students are equally exposed to the language. So there may be other sociolinguistic, as well as paralinguistic factors, that could affect the performance of speakers individually. But it is the position of this study that even when such factors are taken into account, it is not clear that they will so pull together to affect a group of fifty students. This was largely one of the reasons for taking up to that number. Again, it should also be noted that apart from the literature that the members of Group One read in the course of their study, a credit in Literature-in-English is a compulsory requirement for admission. Apart from that, all the students constituting Group One also took Literature in the Universities Matriculation Examination. What this means is that most — if not all —of them have had the opportunity of reading literature since their junior secondary school days up to their current level. But those who constitute the membership of Group Two did not have all of the above opportunities. So this study does not see any other aspect of sociolinguistics that could have influenced the entire group as much as their extra exposure to the language through the vehicle of literature. 
After all the above considerations, which are hugely premised on the results of the analysis, it is concluded that the reading of literature could serve as adequate exposure (or comprehensible input in the words of Krashen) for second language speakers of English, and of course any other second language user.

\section{Conclusions and recommendations for pedagogy}

This study has taken an area of applied linguistics considered to be more or less the most central as far as second language learning is concerned. It may not be an overstatement to say that everything done in every language teaching and learning situation is targeted towards making the learners acquire adequate knowledge that would enable them to communicate effectively in both the written and spoken forms of the language. Even in a first language situation, the linguistic (or in a broader sense, communicative) competence of those acquiring the language is not played with. This is so important that formal teaching of the language takes place in L1 environment, even though there are many other informal means of acquiring the language. All this is to make certain that the speakers of the language acquire the highest possible competence in their language, especially in its practical use. If this level of importance is attached to the development of communicative competence even in first language situations, greater attention should be paid to it in every second language environment, especially in a linguistically plural population like the one for this study. One of the central points this study has established is that the learning of a second language should not be left at an abstract level. This study has proved that second language learning can be enhanced if the learners are given adequate exposure to the language being learned. With the results of this study and those of other studies (for example, Krashen, 1982), it can be concluded that second language learning can be allowed to follow some of the steps of first language acquisition. The result of this study has shown that students who are given the opportunity of encountering the language through literature have the capacity of communicating better in the target language.

The result of this study and related studies have some implications for pedagogy. First, language teaching curriculum at all levels should be designed to include literary texts. Unfortunately, in Nigeria today, unlike it was in the 70's, English language teaching is completely devoid of literature (Akwanya, 2007). Little wonder, the performance of the students in English have continued to nosedive since then. If English language teaching 
curriculum is designed to include literary texts, this study has shown that it can help to improve the communicative competence and performance of the learners.

\section{References}

Akwanya, A. (2005). Language and habits of thought. Third Edition. Enugu: New Generation Books.

Akwanya, A. (2007). English language learning in Nigeria: In search of an enabling principle. Nsukka: University of Nigeria Press.

Akwanya, A. (2010). 'Foreword' in P. Ezema, Strategies for writing effective essays: A guide in essay writing for students in secondary and tertiary institutions. Enugu: Snaap Press.

Al-Darwish, S., \& Shuqair, K. (2015). The use of literature in an EFL classroom. British Journal of Education, 3(7), 71-82.

Aristotle (1920). On the art of poetry (I. Bywater \& G. Murray, Trans). Oxford: Oxford Clarendon Press

Bataineh, R., Rabadi, R., \& Smadi, O. (2013). Fostering Jordanian university students' communicative performance through literature-based Instruction. TESOL Journal, 4(4), 655-673.

Bell, R. (1976). Sociolinguistic approaches and problems. New York: St. Martin's Press.

Canale, M. and Swain, M. (1980). Theoretical bases of communicative approaches to second language teaching and testing. Applied Linguistics, 1(1), 1-47.

Carpio, K., \& Carpio, P. (2015). The importance of considering students' cultural and linguistic backgrounds: Languages are friends, not enemies! Journal of Language Teaching and Research, 6(3), 467-474.

Celce-Murcia, M. (2008). Rethinking the role of communicative competence in language teaching. In E. Soler \& M. Jordà (eds), Intercultural language use and language learning (pp. 41-57). Dordrecht: Springer.

Chomsky, N. (1957). Syntactic structures. The Hague: Mouton.

Chomsky, N. (1965). Aspects of the theory of syntax. Cambridge: The MIT Press.

Crystal, D. (2008). A Dictionary of linguistics and phonetics. Sixth Edition. Oxford. Blackwell.

Cummins J. (1976). The influence of bilingualism on cognitive growth: a synthesis of research findings and explanatory hypotheses. Working Papers on Bilingualism, 9, 143.

de Saussure, F. (1966). Cours de linguistique générale [Course in general linguistics] (W. Baskin, Trans.) In C. Bally \& A. Sechehaye (eds). New York: McGraw-Hill.

Hall, G. (2005) Literature in language education. New York: Palgrave Macmillan.

Hymes, D. (1967). Models of the interaction of language and social setting. Journal of Social Issues, 23(2), 8-38.

Hymes, D. (1972). On Communicative Competence. In J. Pride and J. Holmes (eds), Sociolinguistics: Selected readings (pp. 269-293). Harmondsworth: Pengiun.

Kempson, R. (1979). Semantic theory. Cambridge. Cambridge University Press.

Kramsch, C., \& Kramsch, O. (2000). The avatars of literature in language study. Modern Language Journal, 84, 553-73.

Krashen, S. (1982). Principles and practice in second language acquisition. Oxford: Pergamon Press. 
Osorio, M. \& Insuasty, E. (2015). Analysis of the teaching practices at a Colombian Foreign Language Institute and their effects on students' communicative competence. $\mathrm{HOW}$, $22(1), 45-64$.

Otagburuagu, E. (2007). Literature in language teaching. In E. Otagburuagu, T. Obah, S. Onuigbo \& R. Okorji (eds), Teaching English language skills (pp. 194-198). Nsukka: Anyi-P Printing Press.

Paulston, B. (1992). Linguistic and communicative competence: Topics in ESL. Clevedon: Multilingual Matters.

Rai, A. (2012). Use of literature in teaching English. International Journal of Educational Research and Technology, 3(3), 71-80.

Shazu, R.I. (2014). Use of literature in language teaching and learning: A critical assessment. Journal of Education and Practice, 5(7), 29-35.

Ugwuanyi, K. (2013). Developing the communicative competence of second-language speakers of English through literature. Saarbrucken: LAP LAMBERT Academic Publishing.

Ugwuanyi, K., \& Chukwu, M. (2016). Interrogating the teaching and learning of English in Nigeria: Still in search of an enabling principle. Turkish Online Journal of English Language Teaching (TOJELT), 1(2), 75-84.

Van Ek, J. (1977). The threshold level for modern language learning in schools. London: Longman.

Yano, Y. (2003). Communicative competence and English as an international language. Intercultural Communication Studies, XII, 3, 75-83.

Author's information:

Kingsley Oluchi Ugwuanyi holds BA in English and literary studies and MA in TESEL both at the University of Nigeria, Nsukka, where he also has had a teaching engagement since 2010. He is currently undertaking a doctoral research on the sociolinguistics of Nigerian English at Northumbria University at Newcastle, UK.

Email: kingsley.ugwuanyi@northumbria.ac.uk

comradekings2004@gmail.com

To cite this article:

Ugwuanyi, K.O. (2017). Communicative performance in the written discourse of University of Nigeria undergraduate students: what can literature offer? Bellaterra Journal of Teaching \& Learning Language \& Literature, 10(3), 66-81. DOI: http://doi.org/10.5565/rev/jtl3.705 